\title{
ГОМЕОСТАТИЧНІСТЬ ТА СЕЛЕКЦИЙН ЦІННІСТЬ СУЧАСНИХ СОРТІВ ЯЧМЕНЮ ЯРОГО
}

П. М. Солонечний

Інститут рослинництва ім. В. Я. Юр'єва НААН

У статті наведено результати оцінки гомеостатичності та селекційної цінності 20 сучасних сортів ячменю ярого різного генетичного та географічного походження та семи нових сортів селекції Інституту рослинництва ім. В. Я. Юр'єва НААН в умовах східної частини Лісостепу України в 20102012 pp. Показано ефективність оцінки адаптивного потенціалу генотипу за рівнем гомеостатичності та селекційної цінності. Виділено сорти Взірець, Інклюзив, Доказ, Командор та Модерн як цінний вихідний матеріал для селекції ячменю ярого. Показано перевагу сортів, створених в даній грунтово-кліматичній зоні, над сортами зарубіжної селекції.

Ячмінь ярий, сорт, урожайність, екологічна адаптивність, гомеостатичність, селекиійна чінність, стабільність, пластичність

Стратегія подальшого збільшення врожайності сільськогосподарських культур вимагає заміни традиційних концепцій на нові, зорієнтовані на формування у нових сортів ознак високої адаптивності [1]. Основним завданням селекції зернових культур стає підвищення адаптивного потенціалу у новостворених сортів за умов збереження досягнутого рівня потенційної врожайності $[2,3]$. Урожайність ячменю ярого значно залежить від умов року вирощування, тому для виробництва найбільш цінними $є$ сорти, які здатні максимально реалізувати потенціал свого генотипу в мінливих умовах вирощування. Високоадаптивні сорти здатні забезпечувати досить високі врожаї за сприятливих умов та незначною мірою зменшувати врожай i його якість у несприятливих. Це особливо актуально в умовах сьогочасних глобальних змін клімату та частого недотримання виробниками рекомендованих технологій вирощування. У зв'язку з вищезазначеним при створенні сортів, адаптованих до різних екологічних умов, селекційний матеріал повинен оцінюватись не лише за величиною потенційної врожайності, але й за параметрами адаптивності.

Мета. В даній роботі метою було проведення оцінки адаптивності 20 сортів ячменю ярого, занесених в Державний реєстр сортів рослин, придатних для поширення в Україні та виділення сортів з високою гомеостатичні-

(c) П. М. Солонечний. 2013.

ISSN 0582-5075. Селекція і насінництво. 2013. Випуск 103. 
стю та селекційною цінністю як цінного вихідного матеріалу для селекційних програм ячменю ярого за цими показниками.

Матеріал та методика. В якості вихідного матеріалу для проведення досліджень використано 20 сортів ячменю ярого занесених в Державний реєстр сортів рослин, придатних для поширення в Україні, зарубіжної (Arikada, Jersey, Ksanadu, Maltasia, Mastvinster, Pasadena, Siebastian, Shakira, Sofiara, Омський голозерний) та української (Аспект, Вакула, Взірець, Геліос, Доказ, Етикет, Інклюзив, Командор, Модерн, Парнас) селекції, а також нові сорти селекції Інституту рослинництва ім. В. Я. Юр'єва НААН, що передані до Державного сортовипробування - Аграрій, Алегро, Дивогляд, Щедрий, Косар, Вітраж та Мальовничий.

Дослідження проведено в 2010-2012 рр. в лабораторії селекції та генетики ячменю Інституту рослинництва ім. В. Я. Юр’єва НААН в дослідах конкурсного сортовипробування за загальноприйнятою методикою.

Контрастні за умовами вегетації роки дозволили оцінити досліджувані сорти в мінливих умовах вирощування.

За результатами одержаних даних урожайності було проведено розрахунок статистичних параметрів (середні арифметичні - $X$, мінімальні значення $-X_{\min }$, максимальні значення $-X_{\max }$, розмах варіювання $-R$, коефіцієнт варіації - $V$, коефіцієнт агрономічної стабільності - $A s$, коефіцієнт екологічної пластичності - $b_{i}$, показники гомеостатичності - Hom та селекційної цінності $-S c)$. Статистичний аналіз даних урожайності проведено за Б. А. Доспеховым [4].

Для визначення рівня гомеостатичності (Hom) сортів ячменю ярого використано методику В. В. Хангильдина $[5,6]$, яка грунтується на встановлених в експериментах закономірностях нижчої варіабельності урожаю зерна (продуктивності рослини) та меншим зниженням продуктивності в несприятливих умовах у сортів з високою гомеостатичністю. Дана методика передбачає два варіанти експериментів: вивчення сортів на двох фонах оптимальному та лімітованому (загущення посіву, гірший попередник, тощо) або за даними сортовипробування (за кілька років, за один рік, але при екологічному випробуванні в різних пунктах).

Згідно цієї методики також було розраховано показник селекційної цінності $(S c)$ вищезазначених сортів, який також оцінює ступінь стабільності сорту, але показує трансформований за стабільністю урожай в одиницях виміру.

Для визначення показників екологічної пластичності використано методику S. A. Eberhart i W. A. Russel [7], згідно якої розраховується коефіцієнт регресії $b_{i}$, що характеризує середню реакцію сорту на зміну умов вирощування і дає можливість спрогнозувати зміну досліджуваної ознаки у рамках наявних в досліді умов.

Результати та обговорення. Серед досліджених сортів вітчизняної селекції в 2010-2012 рр. найбільш врожайними виявилися Взірець (4,56 т/га), Інклюзив (4,52 т/га) та безостий сорт Модерн (4,52 т/га), серед іноземних - Jersey (4,40 т/га) та Siebastian (4,33 т/га) (табл. 1). 
Таблиця 1

Параметри адаптивності сортів ячменю ярого в умовах східної частини Лісостепу України, 2010-2012 pp.

\begin{tabular}{|c|c|c|c|c|c|c|c|c|}
\hline \multirow{2}{*}{ Сорт } & \multicolumn{3}{|c|}{ Урожайність т/га } & \multirow{2}{*}{$\begin{array}{l}R, \\
\mathrm{~T} / \Gamma \mathrm{a}\end{array}$} & \multirow{2}{*}{$V, \%$} & \multirow{2}{*}{$A s, \%$} & \multirow{2}{*}{ Hom } & \multirow{2}{*}{$S c$} \\
\hline & $\min$ & $\max$ & $X$ & & & & & \\
\hline Взірець, st & 4,09 & 5,22 & 4,56 & 1,13 & 12,9 & 87,1 & 35,4 & 3,82 \\
\hline Командор, st & 3,83 & 4,32 & 4,05 & 0,49 & 6,1 & 93,9 & 66,1 & 3,59 \\
\hline Arikada & 3,69 & 4,52 & 3,98 & 0,83 & 11,7 & 88,3 & 33,9 & 3,25 \\
\hline Jersey & 3,69 & 4,92 & 4,40 & 1,23 & 14,5 & 85,5 & 30,3 & 3,30 \\
\hline Ksanadu & 3,00 & 4,63 & 3,80 & 1,63 & 20,4 & 79,6 & 19,6 & 2,46 \\
\hline Maltasia & 3,49 & 4,03 & 3,68 & 0,54 & 8,2 & 91,8 & 45,1 & 3,19 \\
\hline Mastvinster & 2,82 & 4,46 & 3,82 & 1,64 & 23,0 & 77,0 & 16,6 & 2,42 \\
\hline Pasadena & 3,08 & 4,57 & 3,83 & 1,49 & 19,5 & 80,5 & 19,7 & 2,58 \\
\hline Siebastian & 3,78 & 5,03 & 4,33 & 1,25 & 14,7 & 85,3 & 29,4 & 3,25 \\
\hline Shakira & 3,10 & 4,90 & 3,98 & 1,80 & 22,6 & 77,4 & 17,6 & 2,52 \\
\hline Sofiara & 3,23 & 5,09 & 4,00 & 1,86 & 24,2 & 75,8 & 16,5 & 2,54 \\
\hline Аспект & 3,26 & 4,84 & 4,17 & 1,58 & 19,5 & 80,5 & 21,2 & 2,81 \\
\hline Вакула & 2,98 & 4,21 & 3,58 & 1,23 & 17,0 & 83,0 & 20,7 & 2,53 \\
\hline Геліос & 2,47 & 4,11 & 3,55 & 1,64 & 26,4 & 73,6 & 13,5 & 2,13 \\
\hline Доказ & 3,91 & 4,51 & 4,12 & 0,60 & 7,4 & 92,6 & 56,2 & 3,57 \\
\hline Етикет & 3,02 & 4,96 & 4,13 & 1,94 & 24,2 & 75,8 & 17,0 & 2,51 \\
\hline Інклюзив & 4,19 & 5,08 & 4,52 & 0,89 & 10,8 & 89,2 & 41,6 & 3,73 \\
\hline Модерн & 3,93 & 5,01 & 4,52 & 1,08 & 12,1 & 87,9 & 37,3 & 3,55 \\
\hline $\begin{array}{l}\text { Омський } \\
\text { голозерний } 1\end{array}$ & 2,19 & 4,20 & 3,40 & 2,01 & 31,2 & 68,8 & 10,9 & 1,77 \\
\hline Парнас & 3,58 & 4,86 & 4,34 & 1,28 & 15,5 & 84,5 & 27,9 & 3,20 \\
\hline $\mathrm{HIP}_{05}$ & & & 0,25 & & & & & \\
\hline
\end{tabular}

Досліджені сорти значно різнилися за амплітудою коливання урожайності. Найбільші коливання урожайності (коефіцієнт варіації $V \geq 20 \%$ ) мали Ksanadu $(V=20,4 \%)$, Mastvinster $(V=23,0 \%)$, Shakira $(V=22,6 \%)$, Sofiara $(V=24,2 \%)$, Етикет $(V=24,2 \%)$, багаторядний сорт Геліос $(V=$ $26,4 \%)$ та Омський голозерний $(V=31,2 \%)$.

Високі рівні розмаху варіювання та коефіцієнтів варіації урожайності певного сорту не можуть вважатися його позитивною характеристикою, проте середній рівень урожайності за ряд років може виявитись досить високим за рахунок високих абсолютних значень. Серед досліджених сортів найбільш урожайними виявились сорти 3 варіабельністю урожайності на рівні 10,8$14,5 \%$ : Взірець $(V=12,9 \%)$, Інклюзив $(V=10,8 \%)$, Модерн $(V=12,1 \%)$, Jersey $(V=14,5 \%)$. Ці сорти реагували на покращення умов вирощування в сприятливі роки та неістотно знижували продуктивність в лімітованих умоваx. 
Найбільш стабільними за урожайністю виявились сорти Командор, Доказ, Maltasia та Інклюзив, які мали найвищі рівні гомеостатичності (Hom $=66,1,56,2,45,1$ та 41,6 відповідно) та агрономічної стабільності (As = 93,9 \%, 92,6 \%, 91,8 \% та 89,2 \%). Вищезазначені сорти найбільш стабільно реалізовували свій потенціал в мінливих умовах вегетації.

Найменш стабільними серед досліджених сортів виявились багаторядний сорт Геліос $(\mathrm{Hom}=13,5 ; A s=73,6 \%)$ та Омський голозерний $(\mathrm{Hom}=$ 10,$9 ; A s=68,8 \%$ ). Омський голозерний значно поступався іншим дослідженим сортам за селекційною цінністю $(S c=1,77)$.

Показник селекційної цінності $(S c)$ дозволив виділити сорти, що поєднують високу або середню урожайність та ії стабільну реалізацію в мінливих умовах вирощування, що $є$ найбільш важливим у виробництві. Серед досліджених сортів найвищі показники селекційної цінності мали сорти Взірець $(S c=3,82)$, Інклюзив $(S c=3,73)$, Доказ $(S c=3,57)$, Командор $(S c=$ $3,59)$ та Модерн $(S c=3,55)$.

Менш адаптовані сорти зарубіжної селекції поступались вітчизняним сортам за рівнем та стабільністю урожайності, що свідчить про великий ризик ї вирощування в даних грунтово-кліматичних умовах. Проте сорти західноєвропейської селекції є цінним вихідним матеріалом для рекомбінаційної селекції ячменю ярого завдяки своїм високим пивоварним якостям.

В рамках досліджень також було визначено параметри адаптивності нових сортів селекції Інституту рослинництва ім. В. Я. Юр'єва НААН, що проходять Державне сортовипробування (табл. 2).

Таблиця 2

Параметри адаптивності нових сортів ячменю ярого селекції Інституту рослинництва ім. В. Я. Юр'єва НААН, 2010-2012 pр.

\begin{tabular}{|c|c|c|c|c|c|c|c|}
\hline Сорт & $\begin{array}{c}\text { Урожайність, } \\
\text { т/га }\end{array}$ & $R, ц / г а$ & $V, \%$ & As, $\%$ & $b_{i}$ & Hom & Sc \\
\hline Взірець st & 4,56 & 1,13 & 12,9 & 87,1 & 1,26 & 35,4 & 3,82 \\
\hline Командор st & 4,05 & 0,49 & 6,1 & 93,9 & 0,54 & 66,1 & 3,59 \\
\hline Алегро & 4,49 & 1,19 & 13,7 & 86,3 & 1,38 & 32,8 & 3,46 \\
\hline Аграрій & 4,42 & 1,25 & 14,8 & 85,2 & 1,46 & 29,8 & 3,35 \\
\hline Щедрий & 4,14 & 0,34 & 4,4 & 95,6 & 0,26 & 94,7 & 3,81 \\
\hline Дивогляд & 3,94 & 0,53 & 7,0 & 93,0 & 0,38 & 56,2 & 3,44 \\
\hline Kocap & 4,22 & 0,94 & 11,3 & 88,7 & 1,13 & 39,1 & 3,57 \\
\hline Вітраж & 4,67 & 1,28 & 13,8 & 86,2 & 1,37 & 33,9 & 3,55 \\
\hline Мальовничий & 4,90 & 1,03 & 11,5 & 88,5 & 1,28 & 42,5 & 3,99 \\
\hline HIP $_{05}$ & 0,33 & & & & & & \\
\hline
\end{tabular}

Новостворені сорти істотно різняться за рівнем екологічної пластичності - сорти Алегро $\left(b_{i}=1,38\right)$, Аграрій $\left(b_{i}=1,46\right)$, Косар $\left(b_{i}=1,13\right)$, Вітраж $\left(b_{i}=1,37\right)$ та Мальовничий $\left(b_{i}=1,28\right)$ добре реагують на покращення 
умов вирощування, тобто є високопластичними.

Більш стабільними за врожайністю були безості сорти Дивогляд $(\mathrm{Hom}=$ 56,2; As =93,0 \%) та Щедрий (Hom = 94,7; As = 95,6 \%), неістотно зменшуючи урожайність в несприятливих (лімітованих) умовах, що пояснюється високою посухостійкістю цих сортів. Сорт Щедрий значно перевищив за рівнем гомеостатичності національний стандарт Командор (Hom $=66,1 ;$ As $=93,9 \%)$.

За показником селекційної цінності кращими виявилися сорти Щедрий $(S c=3,81)$ та Мальовничий $(S c=3,99)$, останній значно перевищив за цим показником національний стандарт Взірець $(S c=3,82)$.

Таким чином, серед нових сортів селекції Інституту рослинництва ім. В. Я. Юр'єва НААН є такі, що перевищують національні стандарти не лише за урожайністю, але й за параметрами адаптивності.

Висновки. Таким чином, внаслідок проведених досліджень показано ефективність оцінки адаптивності сортів ячменю ярого в якості вихідного матеріалу для рекомбінаційної селекції за рівнем гомеостатичності та селекційної цінності. Оцінка гомеостатичності та селекційної цінності має бути обов'язковою складовою вивчення вихідного матеріалу.

За високим рівнем гомеостатичності та селекційної цінності серед досліджених сортів виділено сорти Взірець, Інклюзив, Модерн, Командор, Доказ та Maltasia, які є цінним вихідним матеріалом для селекції ячменю ярого за цими показниками.

Визначено, що сорти зарубіжної селекції переважно поступались сортам вітчизняної селекції як за рівнем урожайності, так і за його стабільністю, що викликано їх меншою адаптованістю до умов вирощування.

Проведено оцінку адаптивного потенціалу нових сортів селекції Інституту рослинництва ім. В. Я. Юр'єва НААН. Сорти диференційовано в залежності від норми їх реакції на зміну умов вирощування і визначено, що сорти Алегро, Аграрій, Косар, Вітраж та Мальовничий є більш пластичними, а сорти Дивогляд та Щедрий мають високу гомеостатичність, тобто стабільно реалізують потенціал свого генотипу в несприятливих умовах.

\section{Список використаних джерел}

1. Опалко А. I. Селекція плодових і овочевих культур: навч. посіб. : Ч. 1.: Загальні основи селекції городніх рослин / За ред. А. І. Опалка. - Умань: НДП «Софіївка» НАН України, 2012. - 340 с.

2. Зимо- и морозостойкость современных сортов озимой пшеницы / В. В. Моргун, В.Ф. Логвиненко, Л. И. Улич [и др.] // Физиология и биохимия культурных растений. - 2000. - Т.32, №4 (186). - С. 255- 260.

3. Корчинский A. A. Селекционно-генетические принципы моделирования сортов пшеницы и ячменя на адаптивность к агроэкологическим условиям выращивания и технологиям возделывания / А. А. Корчинский, А. А. Линчевский, А. П. Орлюк // Наукові розробки і реалізація потенціалу 
сільськогосподарських культур. - К. : Аграрна думка, 1999. - С. 148-154.

4. Доспехов Б. А. Методика полевого опыта (с основами статистической обработки результатов исследований) / Б. А. Доспехов. 5-е изд., доп. и перероб. - М.: Агропромиздат, 1985. - 351 с.

5. Хангильдин В. В. О принципах моделирования сортов интенсивного типа / В. В. Хангильдин // Генетика количественных признаков сельскохозяйственных растений. - М., Наука. - 1978.

6. Хангильдин В. В. Гомеостатичность и адаптивность сортов озимой пшеницы / В. В. Хангильдин, Н. А. Литвиненко // Науч.-техн. бюл. ВСГИ. Одесса, 1981. - Вып. 39. - С. 8-14.

7. Eberhart S. A. Stability parameters for comparing varieties / S. A. Eberhart, W. A. Russel // Crop. Sci., 1966.- Vol. 6. - № 1. - P. 36-40. 